\section{Antimicrobial Effect and Surface Tension of Some Chelating Solutions with Added Surfactants}

Luciano Giardino', Flaviana Bombarda de Andrade², Riccardo Beltrami

\author{
'Scientist Researcher, Crotone, ltaly \\ ${ }^{2}$ Department of Operative \\ Dentistry, Endodontics and \\ Dental Materials, Bauru School \\ of Dentistry, USP - Universidade \\ de São Paulo, Bauru, SP, Brazil \\ ${ }^{3}$ Department of Brain, Behavioral \\ Sciences - Section of Statistics, \\ University of Pavia, Italy
}

Correspondence: Prof. Luciano Giardino, Via Marinella 12, 88900 Crotone, Italia. E-mail: lucianogiardino057@gmail.com

Key Words: Enterococcus faecalis, root canal irrigants, smear layer, surface tension, chelating agents.

\section{Introduction}

Cleaning and shaping of the root canal is of utmost importance for removing pulp tissue, bacteria and debris from the complex root canal system (RCS) (1). Ex vivo studies and clinical evidence have shown that mechanical instrumentation leaves untouched significant portions of the root canal walls and complete elimination of bacteria by instrumentation alone is unlikely to occur (2). Therefore, irrigating solutions should use to improve cleaning and disinfection during root canal preparation (3). Sodium hypochlorite $(\mathrm{NaOCl})$ has excellent antibacterial and dissolving abilities, as reported by several studies (4) and it is the solution of choice during root canal instrumentation. On the other hand, $\mathrm{NaOCl}$ cannot remove the smear layer formed on the canal walls during manual or rotary instrumentation (5). The smear layer may delay or prevent penetration of antimicrobial agents, such as endodontic irrigants. In an ex vivo histological study on human teeth, it has been found that the bactericidal effectiveness of endodontic irrigants depends on their ability to penetrate the infected dentinal tubules and this process is undoubtedly influenced by the presence or absence of smear layer (6). Fogel and Pashley (7) have previously shown that formation of smear layer reduced root dentin permeability after treatment with $5 \% \mathrm{NaOCl}$, but it increased many times after treatment with citric acid.

The use of chelating solutions, such as ethylenediaminetetraacetic acid (EDTA) or citric acid (8), is required to remove the inorganic components of the smear layer. Since 1957, EDTA was recommended and frequently employed for its ability to remove the smear layer (9). Arias Moliz et al. (10) investigated the bactericidal activity of final rinse irrigating solutions against Enterococcus faecalis and found that 17\% EDTA solution showed no bactericidal activity against $E$. faecalis, even after $60 \mathrm{~min}$ of contact. Although EDTA has a long-standing history because it is the most frequently recommended agent for smear layer removal in endodontics, its potential for irritation has been highlighted (11). Therefore, other chelating agents have been suggested to remove the smear layer from instrumented root dentin. The most important requirements for an ideal endodontic irrigant are to have an antibacterial effect and to penetrate deep into the dentinal tubules. In the last few years, new irrigant solutions for smear layer removal with added antimicrobial agents have been developed (12-14).

Surface tension is considered as one of the most important factors in determining the wettability of a solution (15). Wettability is the tendency of a fluid to spread over or adhere to a solid surface. This property is required for the chemical solution to penetrate the main and lateral canals, as well as the dentinal tubules and it depends on the surface tension (16). The aim of this study was to assess the antimicrobial efficacy and to compare the surface tension of MTAD, OMiX and Tetraclean NA irrigating solutions. 


\section{Material and Methods}

The method of this study was based on the procedure previously described by Haapasalo and Ørstavik (17).

\section{Dentin Specimens Preparation}

Bovine central incisors were selected for this study. The apical $5 \mathrm{~mm}$ and two-thirds of the crown were removed from each tooth with a water-cooled rotary diamond saw at $1000 \mathrm{rpm}$ (Isomet Plus precision saw; Buehler, Lake Bluff, IL, USA). The roots were cut into 4-mm-thick slices with a diamond saw as above. The cementum was removed by polishing paper (Ecomet 3, variable-speed grinder-polisher; Buehler), which resulted in a center-holed piece of root dentin with a 6-mm outer diameter. The internal diameter was standardized by an ISO 023 slow speed round bur. The organic and inorganic debris were removed by treating each dentin tube with $5.25 \%$ sodium hypochlorite followed by 17\% EDTA in an ultrasonic bath for 5 min and dipped in distilled water for $10 \mathrm{~min}$. The specimens were then placed in brain heart infusion (BHI) broth (Oxoid, Basingstoke, UK) and autoclaved at $121^{\circ} \mathrm{C}$.

\section{Contamination of Dentin Specimens}

Isolated 24-h colonies of pure cultures of $E$. faecalis (ATCC 29212) were suspended in $5 \mathrm{~mL}$ of BHI broth (Oxoid). The bottles containing each specimen were opened in a laminar flow chamber. Two milliliters of sterile BHI were removed with sterile pipettes and replaced with $2 \mathrm{~mL}$ of bacterial inoculum. The bottles were closed and kept at 37 ${ }^{\circ} \mathrm{C}$ for 21 days, with replacement of $1 \mathrm{~mL}$ of contaminated BHI by $1 \mathrm{~mL}$ of freshly prepared BHI every 2 days, to avoid medium saturation. After the contamination period, the specimens were irrigated with $5 \mathrm{~mL}$ of sterile saline solution to remove the incubation broth. The bacterial growth was verified on three additional contaminated samples with a histological technique and Gram stain (Brown and Brenn staining method), and examined with an Olympus CX41 microscope (Olympus Europe Co Gmbh, Hamburg, Germany) at $400 \times$ magnification.

\section{Root Canal Irrigants}

Three root canal irrigants were used: $\mathrm{QMiX}$, a mixture of EDTA, Chlorhexidine (CHX) and a detergent (cetrimide) (Dentsply Tulsa, OK, USA), BioPure MTAD, a mixture of citric acid, tetracycline isomer (doxycycline) and detergent (Tween 80) (Dentsply), and Tetraclean NA, a mixture of citric acid and detergents (cetrimide + polypropylene glycol) (patent pending).

\section{Antimicrobial Assessment}

Ninety-five specimens, 85 contaminated with $E$. faecalis and 10 not contaminated, were randomly divided into five groups as follows: QMiX, $(n=25)$; BioPure MTAD, $(n=25)$; Tetraclean NA, $(n=25)$; positive control (infected dentin tubes) ( $n=10)$; negative control (sterile saline solution) $(n=10)$. Then, each specimen was removed from its bottle under aseptic conditions, and the root canal was irrigated with $5 \mathrm{~mL}$ sterile saline and dried with sterile paper points. The outer surface of each specimen was covered with two layers of nail polish to prevent contact of the irrigant with the external surface. After that, using decontaminated sticky wax, the specimens were fixed at the bottom of the wells of 24-well cell culture plates, which also obliterated the apical surface of the root canal. Finally, the irrigating solutions were instilled into the canal lumen with sterile 3-mL plastic syringes and \#27 gauge needles until the dentin tubes were filled. The solutions were removed using sterile paper points after $5 \mathrm{~min}$ (BioPure MTAD), $90 \mathrm{~s}$ (QMiX) and $60 \mathrm{~s}$ (Tetraclean NA), according to the manufacturers' recommendations, after placement into the root canal lumen. The specimens were then incubated at $37{ }^{\circ} \mathrm{C}$ for 28 days. At the experimental times of 0, 7, 14, 21 and 28 days, the dentin chips were removed from the root canals using sequential sterile low-speed round burs with increasing ISO diameters: 025, 027, 029, 031 and 033. Each bur removed approximately $0.1 \mathrm{~mm}(100 \mu \mathrm{m})$ of dentin around the canal. The dentin shavings obtained with each bur were carefully collected on sterile aluminum foil to avoid losing dentin chips during the sampling procedure. They were suspended in separate test tubes, each containing $3 \mathrm{~mL}$ of freshly prepared $\mathrm{BHI}$ broth followed by 10 -fold serial dilutions in sterile saline solution. After that, $100 \mu \mathrm{L}$ from each test tube was cultured on blood agar (0xoid). Grown colonies were counted and recorded as CFU (colony-forming units).

\section{Surface Tension Measurement}

The surface tension of the tested liquids was measured using the Wilhelmy plate technique, with a Cahn DCA-322 Dynamic Contact Angle Analyzer (Gibertini Elettronica, Novate (MI), Italy) (16). The calculations of this technique are based on the geometry of the fully wetted glass slide in contact with the liquid. Using this method, a glass slide was immersed in $5 \mathrm{~mL}$ of the test liquid in a beaker cleaned with hot chromic acid, rinsed with MilliQ water and finally air plasma-cleaned in a glow-discharge reactor. The force on the glass slide was recorded continuously by the instrument software as the beaker was raised and withdrawn at the constant speed of $40 \mu \mathrm{m} / \mathrm{s}$, until at least $1 \mathrm{~cm}$ of the glass slide was immersed. For each sample, 15 measurements were taken and mean values calculated.

\section{Statistical Analysis}

Statistical analysis was performed with Stata 12.0 software (Stata, College Station, TX, USA) both for data 
regarding antibacterial effects and for surface tension values. Descriptive statistics, including mean, standard deviation, median, minimum and maximum values were calculated as CFU for antibacterial effects of all irrigating solutions. The normality of the data was calculated using the Shapiro-Wilk test. The Kruskal-Wallis non-parametric ANOVA was applied to determine whether there were significant differences in antibacterial effects among the irrigating solutions. A Dunn test was used post-hoc for multiple comparisons to assess significant differences between each irrigating solution after 28 days. Surface tension values were analyzed initially with a Shapiro-Wilk test. Kruskal-Wallis ANOVA and Dunn tests were then applied to assess the differences among chelating agents. Friedman test was applied to assess the differences over time for each tested irrigating solution. Significance for all statistical tests was predetermined at $p<0.05$.

\section{Results}

The positive control group showed viable bacteria at all experimental times, confirming the efficiency of the methodology. In contrast, the negative control group

Table 1. Descriptive statistics of the CFU data obtained for each irrigating solution. Different capital letters indicate significant differences among irrigating solutions when overall data are tested ( $<<0.05$ ), according to Kruskal-Wallis followed by Dunn tests. Different numerical indexes indicate significant differences over time for each irrigating solutions $(\mathrm{p}<0.05)$

\begin{tabular}{lcccccc}
\hline Time & $\begin{array}{c}\text { Irrigating } \\
\text { solution }\end{array}$ & Obs & Median & Min & Max & Sig. \\
\hline \multirow{2}{*}{ Day 0 } & Tetraclean NA & 125 & 0.22 & 0.04 & 0.46 & 1 \\
& MTAD & 125 & 2.35 & 0 & 4.5 & 5 \\
& Qmix & 125 & 0.9 & 0.66 & 1.34 & 9 \\
Day 7 & Tetraclean NA & 125 & 1 & 0.48 & 1.92 & 2 \\
& MTAD & 125 & 4.37 & 2 & 6.7 & 6 \\
& Qmix & 125 & 3.46 & 2.76 & 4.32 & 6 \\
Day 14 & Tetraclean NA & 125 & 4.82 & 3.28 & 5.9 & 3 \\
& MTAD & 125 & 8.34 & 5.99 & 11.49 & 7 \\
& Qmix & 125 & 7.38 & 4.69 & 11.17 & 7 \\
Day 21 & Tetraclean NA & 125 & 11.5 & 8.21 & 13.57 & 4 \\
& MTAD & 125 & 19.59 & 15.79 & 22.61 & 8 \\
& Qmix & 125 & 12.45 & 8.23 & 14.69 & 10 \\
& Tetraclean NA & 125 & 4.82 & 0.04 & 24.08 & A \\
& MTAD & 125 & 8.34 & 0 & 44.98 & B \\
& Qmix & 125 & 7.38 & 0.66 & 32.96 & B \\
\hline
\end{tabular}

Obs: Number of observations. Min: Minimum. Max: Maximum; Sig.: Significance showed no viable bacteria at all experimental times.

Table 1 shows the average CFU for each irrigating solution. The Kruskal-Wallis ANOVA followed by the Dunn test showed that MTAD had significantly higher CFU values $(p<0.05)$ than Tetraclean NA and QMiX, which were comparable. Figure 1 shows the CFU average values recorded at each time point for each irrigant. The Friedman test showed for all irrigating solutions a significant increase in CFU values over time $(\mathrm{p}<0.0001)$.

Average surface tension values for each irrigant are in Table 2. Tetraclean NA showed significantly lower surface tension values compared to MTAD and QMiX $(p<0.05)$.

\section{Discussion}

Removal of the smear layer produced after root canal instrumentation has been recommended. The bacteria with their by-products and necrotic debris in smear layers compromise the disinfection process (5) and decrease dentin permeability, hampering the diffusion of antimicrobial agents like irrigants into root dentin (6).

EDTA has been suggested and widely used as an irrigation solution because it chelates calcium ions and removes the mineralized portion of smear layers $(5,6,8)$. Although EDTA has a long history as an endodontic chelating agent, it has limited or no antibacterial activity (10) and a high surface tension value (16). In order to overcome these problems, several ways have been suggested like increasing the antibacterial activity of root canal irrigants for the final rinse. One of these ways is to add surfactants and antibiotic (tetracycline) to irrigating solutions. In an attempt to produce an irrigant that could remove the smear layer by its antimicrobial properties, Torabinejad et al. (12) developed a new solution containing a mixture of tetracycline, citric acid and Polysorbate 80 detergent (BioPure MTAD), able to remove both the smear layer and disinfecting the root canal system. Their results showed that BioPure MTAD was useful as a final rinse to remove the smear layer and eradicate bacteria from infected root canals. However, some of these findings have been challenged by other researchers, who found a lower antibacterial activity of BioPure MTAD compared with $\mathrm{NaOCl}$ (18). These results could be correlated with the activity of doxycycline, which has a bacteriostatic

Table 2. Mean surface tension $\left(\mathrm{mJ} / \mathrm{m}^{2}\right)$ for irrigating solutions

\begin{tabular}{lcc}
\hline Irrigating solution & Obs & Mean \pm Std. Dev. \\
\hline Tetraclean NA & 15 & $28.91 \pm 0.95^{*}$ \\
MTAD & 15 & $34.54 \pm 0.76$ \\
Q-mix & 15 & $36.43 \pm 0.48$ \\
\hline
\end{tabular}

Kruskal-Wallis ANOVA followed by Dunn test. ${ }^{*} \mathrm{p}<0.05$ vs MTAD and Q-mix. Std. Dev.: standard deviation. Obs= Number of observations. 
action and cannot kill bacteria. The addition of cetrimide (CTR) to replace Tween 80 may increase the antibacterial activity of solutions like EDTA, citric acid and BioPure MTAD (22). CTR is a cationic surfactant, which combined with chelating agents, has greater antimicrobial activity than the chelating irrigants alone (20).

QMiX, a non-antibiotic single solution used as a final rinse after $\mathrm{NaOCl}$ for one-step smear layer removal and disinfection, was introduced in 2011. This is a premixed and ready to use irrigating solution that contains EDTA, chlorhexidine ( $\mathrm{CHX}$ ) and a detergent (cetrimide), with $\mathrm{pH}$ slightly above neutral. This irrigant has demonstrated antibacterial activity comparable to $\mathrm{NaOCl}$ and superior activity against planktonic and biofilm bacteria compared to $2 \%$ CHX and MTAD (13). Contrarily, Ordinola-Zapata et al. (21) observed the poor antibacterial activity when QMiX was applied for 5 min on multispecies biofilm from oral microbiota. Tetraclean NA is a new combination that contains citric acid, cetrimide and polypropylene glycol without antibiotic. Recently, a comparative study (22) indicated satisfactory antibacterial activity of Tetraclean NA on root canals infected with $E$. faecalis for 60 days. The current in vitro study compared the antimicrobial activity of different low surface tension chelating agents with on root canals infected with $E$. faecalis after variable time intervals and their surface tension values.

The results of the present study showed that Tetraclean NA had the lowest CFU values, while the highest CFU counts resulted from MTAD (Fig. 1, Table 1). These findings are not a surprise, because Tween 80 (Polysorbate 80), a detergent present in MTAD, has limited or no activity as an antibacterial agent (23) and it may neutralize various substances (24). According to Pappen et al. (19), modifications of MTAD where CTR replaced Tween 80 were more effective against $E$. faecalis and polymicrobial biofilm than MTAD, confirming that CTR improved the antimicrobial properties of the solutions, whereas Tween 80 seemed to have a neutral or negative impact on their antimicrobial effectiveness. The lower antibacterial activity of QMiX compared to Tetraclean NA, as observed in the present study, is due to the different composition and concentration of detergents and chelating agents in the two irrigating solutions. QMiX has a lower content of $\mathrm{CHX}$ and cetrimide, while Tetraclean NA is an irrigant mixture that contains more cetrimide and citric acid than QMiX. Citric acid as well as cetrimide has antibacterial efficacy and previous studies highlighted that citric acid shows antimicrobial activity against anaerobic bacteria of the infected root canals, in particular against cocci (25).

In a recent study, Poggio et al. (14) compared the decalcifying capacity of different irrigating solutions at different contact times and observed a significantly higher release of $\mathrm{Ca}^{2+}$ in samples exposed to citric acid-based agents, including Tetraclean NA, than EDTA solutions in the presence or absence of cetrimide. The higher release reported in that study may be due to the lower $\mathrm{pH}$ of the citric acid solutions $(\mathrm{pH}<2)$, thus increasing the removal of inorganic elements such as calcium from the hydroxyapatite
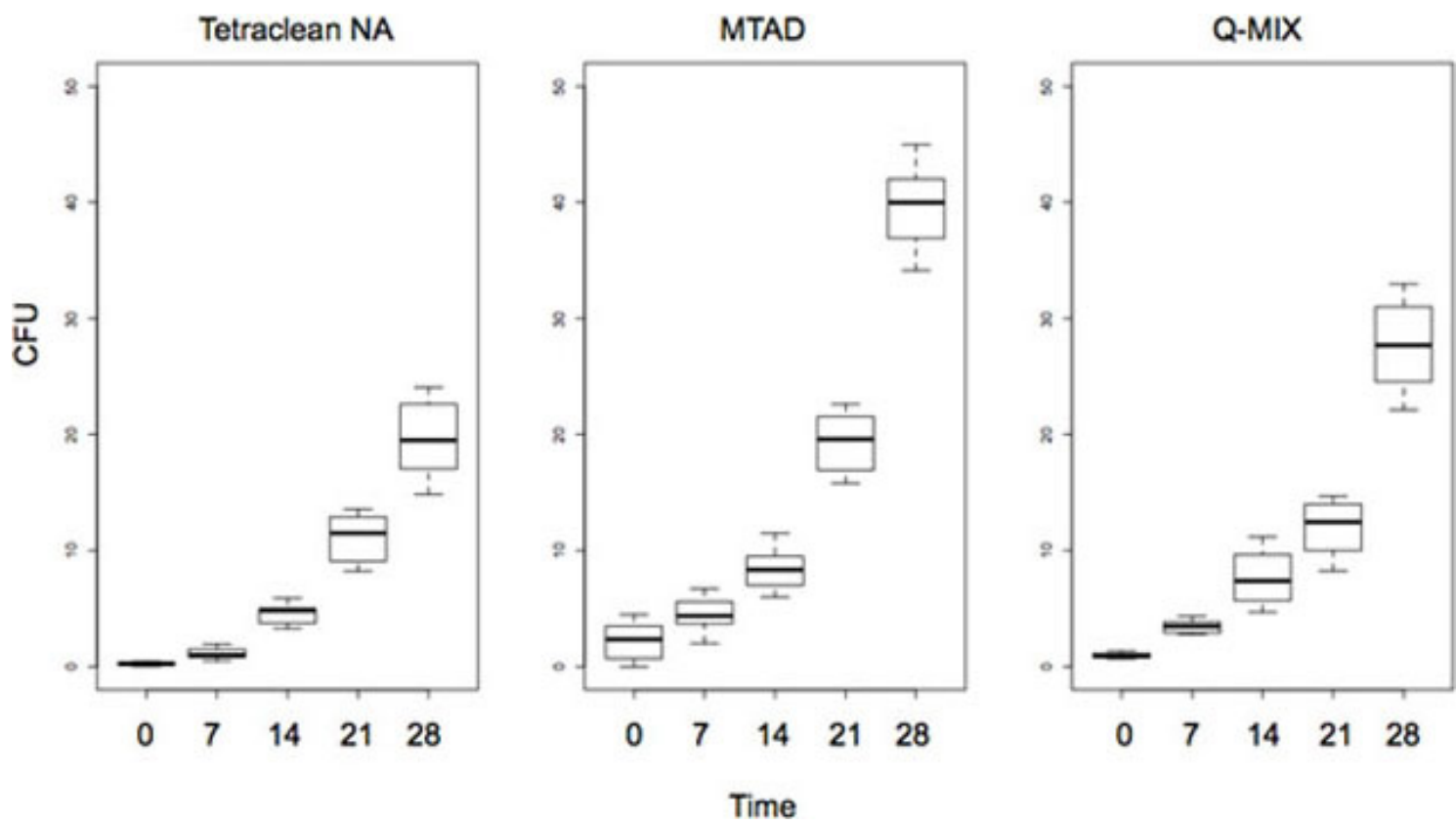

Figure 1. Box-plot of CFU values and antibacterial effects for each irrigating solution at different times. For each employed irrigant, the median value, the minimum and the maximum values were indicated. 
crystals, agreeing with previous results (8).

The present study also compared the surface tension of three chelating solutions modified with detergents and demonstrated that Tetraclean NA had significantly lower surface tension values compared to MTAD and QMiX (Table 2). In view of what has been observed in this investigation, the better antibacterial action of Tetraclean NA may be explained by its low $\mathrm{pH}$ (unpublished laboratory results), low surface tension and better removal of the smear layer (data not published), all of which improve its penetration into the root canal and the dentinal tubules. Further studies should be performed to confirm the promising results observed in this in vitro study.

In conclusion, Tetraclean NA and QMiX showed significantly better antibacterial activity and lower surface tension values compared to MTAD.

\section{Resumo}

Este estudo avaliou a eficácia antimicrobiana e tensão superficial de soluções irrigadoras e uma nova solução quelante em tubos de dentina infectada. Vinte e cinco espécimes foram aleatoriamente distribuidos conforme as soluções irrigantes. Decorrifdos 21 dias de contaminação com E. faecalis, a soluções de irrigação MTAD, QMiX e Tetraclean NA foram distribuídas em cada canal radicular infectado. As soluções foram removidas e as amostras de dentina foram retiradas dos canais radiculares com brocas esféricas de baixa velocidade com diâmetros ISO - sucessivamente maiores. As amostras do pó de dentina obtidas com cada broca foram imediatamente colocadas em tubos de ensaio separados contendo $3 \mathrm{~mL}$ de caldo BHI. A seguir, $100 \mu \mathrm{L}$ de cada amostra do tubo de teste foi cultivada em agar de sangue. As colônias crescidas foram contadas e registadas como unidades formadoras de colônias (UFC). A tensão superficial das soluções irrigantes foi medida utilizando o método de Wilhelmy. A análise não paramétrica de Kruskal-Wallis e o teste de Friedman foram utilizados $(p<0,05)$. Tetraclean NA apresentou menor tensão de superfície e menores valores de UFC do que MTAD e QMiX. A melhor ação antibacteriana e baixa tensão superficial foram observadas para Tetraclean NA, provavelmente devido à melhor penetração no canal radicular e túbulos dentinários.

\section{Acknowledgements}

The authors wish to thank Dr. Zahed Mohammadi, Iranian Center for Endodontic Research (ICER), Research Institute of Dental Sciences, Dental School, Shahid Beheshti University of Medical Sciences, Tehran, Iran, for helping with dentin specimens preparation and antibacterials tests

\section{References}

1. Schilder H. Cleaning and shaping the root canal. Dent Clin North Am 1974;18:269-296.

2. Peters OA, Laib A, Gohring TN, Barbakow F. Changes in root canal geometry after preparation assessed by high-resolution computed tomography. J Endod 2001;27:1-6.

3. Siqueira JF, Lima KC, Magalhaes FAC, Lopes HP, de Uzeda M. Mechanical reduction of the bacterial population in the root canal by three instrumentation technique. J Endod 1999;25:332.

4. Mohammadi Z. Sodium hypochlorite in endodontics: an update review. Int Dent J 2008;58:329-341.

5. McComb D, Smith DC. A preliminary scanning electron microscopic study of root canals after endodontic procedures. J Endod 1975;1:238242.

6. Berutti $E$, Marini $R$, Angeretti A. Penetration ability of different irrigants into dentinal tubules. J Endod 1997:23:725-727.

7. Fogel HM, Pashley DH. Dentin permeability: effects of endodontic procedures on root slabs. J Endod 1990;16:442-445.

8. Scelza MF, Teixeira AM, Scelza P. Decalcifying effect of EDTA-T, 10\% citric acid, and 17\% EDTA on root canal dentin. Oral Surg Oral Med Oral Pathol 2003;95:234-236.

9. Torabinejad $M$, Handysides $R$, Khademi AA, Bakland LK. Clinical implications of the smear layer in Endodontics: a review. Oral Surg Oral Med Oral Pathol Oral Radiol Endod. 2002;94:658-666.

10. Arias-Moliz MT, Ferrer-Luque CM, Espigares-Rodríguez E, LiébanaUreña J, Espigares-Garcia M. Bactericidal activity of phosphoric acid, citric acid, and EDTA solutions against Enterococcus faecalis. Oral Surg Oral Med Oral Pathol Oral Radiol Endod 2008;106:e84-e89.

11. Scelza MF, Daniel RL, Santos EM, Jaeger MM. Cytotoxic effects of $10 \%$ citric acid and EDTA-T used as root canal irrigants: an in vitro analysis. J Endod 2001;27:741-743.

12. Torabinejad $M$, Shabahang $S$, Aprecio RM, Kettering JD. The antimicrobial effect of MTAD: an in vitro investigation. J Endod 2003;29:400-403.

13. Stojicic $S$, Shen $Y$, Qian W, Johnson B, Haapasalo M. Antibacterial and smear layer removal ability of a novel irrigant, QMiX. Int Endod J 2012;45:363-371.

14. Poggio C, Dagna A, Vinci A, Beltrami R, Cucca L, Giardino L. Decalcifying capability of irrigating solutions on root canal dentin mineral content. Contemp Clin Dent 2015;6:201-205.

15. Lopes HP, De Faria AR, Alves FRF, Elias CN. Wettability of irrigants used in root canal treatment. Dentistry 2015;5:283.

16. Giardino L, Ambu E, Becce C, Rimondini L, Morra M. Surface tension comparison of four common root canal irrigants and two new irrigants containing antibiotic. J Endod 2006; 32:1091-1093.

17. Haapasalo $M, \emptyset$ rstavik D. In vitro infection and disinfection of dentinal tubules. J Dent Res 1987;66:1375-1379.

18. Dunavant TR, Regan JD, Glickman GN, Solomon ES. Comparative evaluation of endodontic irrigants against Enterococcus faecalis biofilms. J Endod 2006;32:527-531.

19. Pappen FG, Shen Y, Qian W, Leonardo MR, Giardino L, Haapasalo M. In vitro antibacterial action of Tetraclean, MTAD, and five experimental irrigation solutions. Int Endod J 2010;43:528-535.

20. Ferrer-Luque CM, Conde-Ortiz A, Arias-Moliz MT, Valderrama MJ, Baca $P$. Residual activity of chelating agents and their combinations with cetrimide on root canals infected with Enterococcus faecalis. J Endod 2012;38:826-828.

21. Ordinola-Zapata $\mathrm{R}$, Bramante $\mathrm{CM}$, Garcia RB, Andrade FB, Bernardineli $N$, Moraes IG, et al.. The antimicrobial effect of new and conventional endodontic irrigants on intraorally infected dentin. Acta Odontol Scand 2013;71:424-431.

22. Giardino L, Estrela C, Generali L, Mohammadi Z, Asgary S. The in vitro effect of irrigants with low surface tension on Enterococcus faecalis. Iran Endod J 2015;10:174-178.

23. Dawson, R. M. C., D. P. Elliott, W. H. Elliott, K. M. Jones. 1986. Data for biochemical research, 3rd ed. Oxford University Press, New York, NY. p. 289.

24. Metzger Z, Basrani B, Goodis HE. Instruments, Materials, Devices. in: Cohen's Pathways of the Pulp. 10th ed. Mosby Inc., St Louis; 2011: 251-252.

25. Georgopoulou M, Kontakiotis E, Nakou M. Evaluation of the antimicrobial effectiveness of citric acid and sodium hypochlorite on the anaerobic flora of the infected root canal. Int Endod J 1994;27:139-143.

Received April 20, 2016 Accepted August 8, 2016 